\title{
ECOLOGY OF SUNDARBAN, BANGLADESH
}

\author{
M R Rahman ${ }^{1}$ and M Asaduzzaman ${ }^{2}$
}

\begin{abstract}
Sundarban is the largest mangrove wetland in the world. It covers an area of about $1 \mathrm{mha}$, of which $60 \%$ is located in Bangladesh and the remaining western portion, comprising $40 \%$, lies in India. Mangrove ecosystems are of great ecological significance in the tropical and sub-tropical coast. They protect our coast from heavy wind, tidal waves, coastal erosion and sea water intrusion, generate substantial quantities of fishery resources and provide many useful forestry products. The Sundarban ecosystem supports rich fisheries diversity. This ecosystem support 27 families and 53 species of pelagic fish, 49 families 124 species of demersal fish, 5 families and 24 species of shrimps, 3 families and 7 species of crabs, 8 species of lobster. A total 334 plants, 165 algal, 13 special orchids, 17 fern, 87 monocotyledon and 230 dicotyledon belonging to 245 genera and 75 families from the sundarbans and adjacent area are found available. The principal tree species is Sundry (Heritiera fomes) which covers about $73 \%$ to total landmass and the second species is Gewa (Excoecaria agallocha) which covers about $16 \%$ of total forest area. The plant species include 35 legumes, 29 grasses, 19 sedges, and 18 euphorbias. Of the 50 true mangrove plant species recorded throughout the globe, the Sundarbans alone contain 35 species. The magnificent among the animals on land is Royal Bengal Tiger, Spotted deer, barking deer and wild boars are there in plenty. Besides those jungle cats, fishing cat, civet cat, monkey, bengal fox, jackle, water monitor, monitor lizard and snakes are important faunal spp. Moreover, abundant of the Sundarbans are purple heron, pond heron, cattle egret, little egret, open billed stork, smaller adjutant stork, brahmini kite, spotted dove, rose ringed parakeet, crow pheasant, wood pecker, bee eater, drongo, pide myna, jungle myna, bulbul, tailor bird, magpie robin, sparrow etc., Otherwise, recorded that wild Buffalo, 2 species of deer, javan rhinoceros extinct and presently 2 species of amphibians, 14 species of reptiles 25 species of birds and 5 species of mammals are considered as endangered species. This paper is to produce a new assessment of the mangroves ecology of Sundarbans.
\end{abstract}

Keywords: Ecology, Sundarbans, Bangladesh

\section{INTRODUCTION}

The ganges floodplain and the sundarban ecosystem cover a large area in the southwestern part of Bangladesh. Ecology of the sundarban areas are rapidly changing due to Farakka Barrage, deforestration, cyclone, industrial pollution etc. Bunt et al., 1982; Blasco 1984; Thom 1984; Alongi et al. 1992; Woodruff 1992; Duke 1992, Smith 1992 works on different aspect of ecosystem of Sundarbans. Christensen, 1984; Khan, 1986; Baidya and Choudhury, 1986; Choudhury and Choudhury 1994; Swaminathan 1994; Siddiqi 1999 and 2001; Blasco and Aizparu 2002 observed their studies on Mangrove ecology. Islam 1973; Hendrich 1975; Mukherjee 1975; Olivier 1979; Hussain et al. 1983; Habib 1989 and Chaffey and Sadom 1985 described their article on flora and faunal diversity of sundarban ecosystem.

\footnotetext{
${ }^{1}$ Institute of Environmental Science, University of Rajshahi, Rajshahi-6205, Bangladesh

${ }^{2}$ Executive Director. Bangladesh Science Foundation, Dhaka, Bangladesh.
} 
The UNESCO has declared three sanctuaries in the sundarbans as World Heritage Site in 1997. The Sundarban is the richest habitat in the lower Bengal Basin for a variety of faunal species, the last stronghold of the Royal Bengal Tiger (Panthera tigris). Studies (Seidenstiker and Hai 1983; Salter 1984; Blower 1985 and Khan 1986 as cited by Hussain and Acharya 1994) revealed that the Bangladesh Sundarbans supports diverse biological resources.

The Sundarbans is contributing in various ecosystem services like soil formation, soil protection, and regulation of hydrological cycle, moisture contents, evaporation, climate and protection of the country from natural calamities (Kathiresan and Bingham 2001).

The glorious sun rise or enchanting sunset in the Sundarbans forest can be a 'Joy for ever' Most frequently visited sites in the Sundarbans include Katka, Nilkamal (known commonly as Hiron Point), Dublar Char and Tiger Point (Kachi Khali) (ASB, 2004). Siddiqui (2009) reported that during the period of one year (2007-2008) 83,709 national and 1,479 international tourists visited the Sundarbans contributing taka 27.45 lakh as revenue whereas Department of Forest, Dhaka office mentioned that tourists have contributed Tk.167.23 lakh $(\mathrm{DoF})$ as revenue in the last six years.

Mangrove wetlands act as a barrier against cyclones, avoid coastal erosion and provide nursery grounds for a number of commercially-important fish, prawns and crabs. Some of these mangrove wetlands play an important role in enhancing the fishery production of the adjacent neritic waters by exporting organic and inorganic nutrients (Alongi et al. 1992). The environmental setting of this multiple-use ecosystem is governed by physical forces such as geomorphology of the coast, climate, tidal amplitude and duration, and quantity of freshwater inflow (Blasco 1984).

The main objective of this paper is to assess the existing conditions of ecosystem, biodiversity, causes of loss of natural resources, salinity intrusion and other related factors.

\section{MATERIALS AND METHODS}

Most of the data were collected from secondary sources. All previous data and reports were collected from forest department of Khulna and Dhaka and internet web pages. For collecting primary data six categories of questionnaires have been used. The set of questionnaires have been designed to be used by the officials like divisional forest officers, range officers, deputy forest rangers, and forest rangers etc of the forest department tasked with overseeing the sundarban forest; the second set of questionnaire have been made to be used by the employees like forester, guard and boatman etc.; the third, by the wood cutters, the fourth, by the bawali (people involved in collecting goal patta); the fifth, by the mawali (people involved in honey and wax extractions); and the sixth, by the local people.

To produce some statistics at a (i.e. at a relatively small scale), the classification system had to be simplified, hence the priority was to discriminate from space and to delineate the following classes: dense (tall or low) mangroves (including unexplained top dying), degraded mangrove or young stands, very degraded mangrove or young stages, mangrove afforestation areas, active deforestation activities (hot spots) and mangrove areas converted to other uses.

Dense mangroves- the canopy is dense and evergreen; such an ecosystem or group of ecosystems is hardly subject to visible degradation processes, from space. This class includes, in the sunderban, an area which corresponds to an unexplained mortality of some mangrove trees (Heritiera fomes). Degraded and very degraded mangrove stages-this is a broad class in which most degraded stages are grouped, although at a local or a national levels, additional distinctions would be needed. Mangrove afforestation areas -this extremely ambitious coastal management activity is commented in the section related to the sundarban. Active deforestation activity (or hot spots)- deforestation and wood extraction are major causes, yet poorly documented, of mangrove depletion in many parts of the world. Monitoring activities are to be focused mainly on those areas where active deforestation 
practices were observed and should be considered as 'hot spots' for the survival of rare plant communities.

\section{Methods of studding Mangroves}

Data to be collected and processed in the following steps-the study site will be selected using GPS, transact line is perpendicular to the shoreline, the plot dimension is $10 \mathrm{~m} \times 10 \mathrm{~m}$, within each plot counts are made for tree counts and in $1 \mathrm{~m} \times 1 \mathrm{~m}$ sub plot counts are made for seedling and sapling, counting the numbers of three class of maturity viz., trees, sapling and seedling by species within the plot, sapling between $1-4 \mathrm{~m}$ and seedling below $1 \mathrm{~m}$ are counted species wise for numbers.

Densities is measured species wise and total in each plot as follows, density of each species (no/ha)= no. $\times 10,000 \mathrm{~m}^{2} /$ area of plot in $\mathrm{m}^{2}$ and total density of all species=sum of all species densities.

\section{RESULTS AND DISCUSSION}

The Sundarbans $\left(21^{\circ} 30^{\prime}-22^{\circ} 30^{\prime} \mathrm{N}, 89^{\circ} 12^{\prime}-90^{\circ} 18^{\prime} \mathrm{E}\right)$ are a World Heritage Site which consists of three wildlife sanctuaries (Sundarbans West, East and South) lying on disjunction deltaic islands in the Sundarbans Forest Division of Khulna District, close to the border with India and just west of the main outflow of the Ganges, Brahmaputra and Meghna rivers.

The forest cover an area of $6017 \mathrm{~km}$ square, of which $4143 \mathrm{~km}$ square are landmass and remaining $1874 \mathrm{~km}$ square are under water bodies in forms of rivers, canals and creeks. The areas $99 \%$ covered by the districts of Sathkhira, Khulna and Bagerhat while other areas are in Patuakhali and Barguna districts. At least $85 \%$ of India's mangroves are found in the east coast where rivers and estuaries are more extensive than on the coast of the Arabian Sea. The average figures available in 1975 for the east coast of India are as follows: Cauvery delta $15 \mathrm{~km}^{2}$, Krishna and Godavari deltas $100 \mathrm{~km}^{2}$, Mahanadi delta $50 \mathrm{~km}^{2}$, Sundarbans (West Bengal-Ganges) $2000 \mathrm{~km}^{2}$, Total $2165 \mathrm{~km}^{2}$ (Blasco and Aizpuru 2002).

Total area of Bangladesh section of Sundarbans is 595,000 hectares (ha) of which 139,699ha are protected as follows: Sundarbans West Wildlife Sanctuary with 71,502ha; Sundarbans East Wildlife Sanctuary with 31,226ha; and Sundarbans South Wildlife Sanctuary with 36,970ha. Sundarbans National Park (133,010ha), a World Heritage Site, lies to the west in India.

\section{Rainfall}

The mean annual rainfall in the region with $80 \%$ probably varies from about $2000 \mathrm{~mm}$ in the east and $1600 \mathrm{~mm}$ in the west. The rainy season is June to September and October to February winter. Eighty to eighty five percent of annual rainfall occurs during the monsoon season from May to September.

\section{Temperature}

Higher temperature $\left(26-34^{0} \mathrm{C}\right)$ occur during March to June and lower temperatures $\left(12-25^{\circ} \mathrm{C}\right)$ during December to February. The main annual maximum temperature is $31.3^{\circ} \mathrm{C}$ at Satkhira, the western part of the Sundarbans while mean annual maximum $29.4^{\circ} \mathrm{C}$. Temperature normally influences growth and development of the regeneration and growing stock of the Sundarbans.

\section{Relative Humidity}

The annual relative humidity varies from $70-80 \%$. June to October is the month of high humidity and lowest on February.

\section{Wind}

The south-westerly monsoon starts from about middle of March, and records about the end of September. The monsoon winds blow from the south with sustained force from March to October. The prevailing winds are from the north and northeast in January. February is calm month with foggy mornings. 


\section{Cyclones and Storms}

Several cyclones may also occur in October and November. Cyclones are accompanied by tidal surge and autumnal storm. The frequency appears to be increasing during the $20^{\text {th }}$ century from 1 in 3 years in 1950 to 1 in 2 years now. The storms and tidal surge can cause several damage of forest, agricultural crops, fishery and human settlements.

\section{Slope length}

Sloping towards the streams are generally formed along channel deposition and thus mud flats are form. Slope length some time hampers growth status of the regeneration.

\section{River Systems}

The sundarban reserve forest is intersected by an elaborate network of rivers, channels and creeks with varying width and length and occupy an area of $18,741 \mathrm{~km}^{2}$. Depending upon the manner in which the tidal wave propagates through the major rivers systems, the rivers in the sundarbans are classified in three different series i.e., Raimangal-Sibsa series, Passur-Sibsa series and PassurBaleswar series. From east to west the river systems also comparise four estuaries viz., Bangra estuary, Kunga estuary, Malancha estuary and Raimangal estuary.

\section{Tidal Inundation}

The tidal inundation sweeps over entire Sundarbans twice a day and tidal current changing its direction after every six hours. The maximum rise and fall occurs during the spring tides in March and April. The effect of the tide is far into the interior and the rise and fall tends to be content throughout the year and varies only with the phases of the moon. Tidal inundation is only media to transfer the seeds elsewhere in the Sundarbans.

\section{Water salinity}

Water salinity increase during monsoon and it indicated the seasonal variability of soil salinity correlated with the variability of river water discharge. Burigoalini, the western zone salinity level is high 28ppt and Supati, eastern part 5ppt, Dhangmari 8ppt and Katka 20ppt on March and at the month of September it decrees and other times also varies.

\section{Soil salinity}

Soil salinity in April-May remains between 5.2 to $16 \mathrm{mmhos} / \mathrm{cm}$ in most parts of the Sundarbans in dry season and during rain 0.65 to $8.97 \mathrm{mmhos} / \mathrm{cm}$. Peak salinity level occurs in March-May and drops gradually in the soil and abruptly in water after June.

\section{Salinity Intrusion}

In south-west Bangladesh thus salinity intrusion has been increased gradually after post-diversion period by the upstream Farakka barrage. The salinity of the area has been increased from 380 micromhos during the pre-diversion period in 1974 to about 29,500 micromhos in 1992. In addition, the salinity level of 500 micromhos during the post-diversion period engulfed about 12,000 square miles compared to 7,000 square miles during the pre-diversion period.

In the present investigation, 68 percent forest resources have been reducing during the 1985-2000 period. On an observation, 85525 trees from the forest department's top dying marking and felling registers revealed that that 17 percent of top dying trees were totally dead.

The scientific literature available today is abundant and covers an imposing array of topics such as ecology, salinity intrusion, phytochemistry, remote sensing and soils, aquatic and terrestrial mammals such as dolphins, these deer and tigers, microfungi, afforestation practices, productivity, biodiversity etc.

The salinity intrusion situation aggravated by the decreasing upstream fresh water flow and silting in the major channels meeting the estuary. Salinity affects severely biodiversity of the area. According to the forest department officials, about 75 lakh trees of Khulna and Satkhira have been affected with top 
dying diseases. Presently found that out of 55 compartments in the sundarbans 22 compartments have been badly affected by top dying of sundry.

\section{Soil pH}

The sundarbans soil is slightly alkaline to neutral with a $\mathrm{pH}$ of 5 to $6.8 \mathrm{pH}$ in the field assessed. Soil is found to vary 6.8 to 5.0 where organic mater deposition is high. $\mathrm{pH}$ of soil ranges from 5.0 to $6.8 \mathrm{pH}$ also depends on in presence of high organic mater in soil.

\section{Chloride}

$\mathrm{Na}, \mathrm{K}$ and $\mathrm{Ca}$ content are lower in the eastern rivers than the western rivers. An increase in the amount of these elements was also observed in areas towards the sea.

\section{Freshwater Flush}

Upstream water flush and soil water salinity directly depends on growth, remain sound and biodiversity conservation of the Sundarbans. The present increase in salinity has been attributed to the decrease of freshwater discharge in the rivers.

\section{Sedimentation}

With the extensive network of rivers and channels, some of these sediments are deposited on the forest floor of the sundarbans and remaining sediments is carried into the Bay of Bengal. Some of these sediments may also be re-deposited on the forest floor during high tides.

\section{The Gangetic delta (India and Bangladesh)}

In spite of a large amount of literature available today on the Sundarbans, our ecological knowledge remains meager and scattered. Almost all management practices that are applied in these mangroves, like inmost mangroves of the world, are primarily the result of empirical expertise often provided by foresters. Such fields as primary productivity, plant animal interactions, micro-organisms and nutrient cycling in mangrove soils and waters etc. which constitute essential knowledge for management practices on a long term sustained yield basis, are practically unex-his very valuable resource called as 'Sundarbans' is protected and managed in India and Bangladesh since more than 70 years. The most valuable timber is Heritiera fomes (local name sundri).

As the matter of fact the dieback of Heritiera fomes raises obvious economic and ecological issues particularly related to its causes and to the development of new successional stages. The mortality which affects one species does not create here important gaps in the ecosystems. This means that light demanding species often found on higher mangrove soils are able to settle soon after the felling of sundri. According to known auto-ecological behaviours Excoecaria agallocha and some Rhizophoraceae members (Ceriops or Bruguiera) are likely to be the first pioneers in open stations.

In addition to this variety of natural mangrove types, the Ganges delta now has important coastal afforested areas in several islands located offshore from Bangladesh that can be observed and mapped with high resolution satellite data. Their density in the field some times does not exceed $30 \%$. Two main species used are: Sonneratia apetala Buch.-Ham (80\% of mangrove plantation, especially in islands where the salinity is lower - about $20 \%$ i.e. Rangabal and Kukri islands) and Avicennia officinalis L. which is planted in the eastern coastal belt where the salinity of the water is higher about $25 \%$.

According to our satellite observations, the rate of survival and growth seem to be different from one place to another. If the afforestation programme in Bangladesh which began in 1966 has involved about 160,000ha, the global apparent rate of success is about $50 \%(80,000 \mathrm{ha})$.

\section{Physical Features}

The Sundarbans, is approximately half the size of the area of mangrove that existed 200 years ago, the other half being cleared and converted to agricultural land.

The land is molded by tidal action, resulting in a distinctive physiography. An intricate network of interconnecting waterways, of which the larger channels of often a mile or more in width run in a 
generally north-south direction, intersects the whole area. Innumerable small khals drain the land at each ebb.

Rivers tend to be long and straight, a consequence of the strong tidal forces and the clay and silt deposits which resist erosion. Easily eroded sands collect at the river mouths and form banks and chars, which are blown into dunes above the high-water mark by the strong south-west monsoon. Finer silts are washed out into the Bay of Bengal but, where they are protected from wave action, mud flats form in the lee of the dunes. These become overlain with sand from the dunes, and develop into grassy maddens. This process of island building continues for as long as the area on the windward side is exposed to wave action. With the formation of the next island further out, silt begins to accumulate along the shore of the island and sand is blown or washed away. Apart from Baleswar River the waterways carry little freshwater as they are cut off from the Ganges, the outflow of which has shifted from the Hooghly-Bhagirathi channels in India progressively eastwards since the 17th century. They are kept open largely by the diurnal tidal flow.

Alluvial deposits are geologically very recent and deep. The soil is a silty clay loam with alternate layers of clay, silt and sand. The surface is clay except on the seaward side of islands in the coastal limits, where sandy beaches occur. In the eastern part of the Sundarbans the surface soil is soft and fertile, whereas it is harder and less suitable for tree growth in the west. The potential of hydrogen $(\mathrm{pH})$ averages 8.0.

\section{Climate}

Rainfall is heavy and humidity high (80\%) due to the proximity of the Bay of Bengal. About $80 \%$ of the rain fall in the monsoon, which lasts from June to October. There is a six-month dry season during which evapotranspiration exceeds precipitation. Conditions are most saline in February-April, the depletion of soil moisture being coupled with reduced freshwater flow from upstream. Temperatures rise from daily minima of 2-4 degrees Celsius $\left({ }^{\circ} \mathrm{C}\right)$ in winter to a maximum of about $43^{\circ} \mathrm{C}$ in March and may exceed $32^{\circ} \mathrm{C}$ in the monsoon. Storms are common in May and October-November and may develop into cyclones, usually accompanied by tidal waves of up to 7.5 meters high. Climatic data for Khulna are summarised by Christensen.

\section{Faunal Diversity}

The mangrove ecosystem is more dynamic, unique and complex. The fauna is environmentally interacted in the process of ecosystem. At least as per go knowledge 42 species of mammal among them 25 important mammalian species (Sancus murinus, Cynopterus sphinx, Pteropus giganteus, Magaderma lyra, Coelops frithi, Macaca mulatta, Dremomys sp., Vandeleurea oleracea, Bandicita indica, Rattus rattus, M. booduga, Hystrix hodgsoni, Sotalia plumbea, Delphinus delphis, Occaella brevirostris, Platanista gangetica, Vulpes bengalensis, Canis aureus, Herpestes edwardsi, Panthera tigris, Felis viverrina, F. chaus, Sus scrofa, Mantiacus muntijak and Axis axix) are known to occur in the sundarban and adjacent area. The present population of the Royal Bengal Tiger in the sundarban is nearly 450.

Eight species of amphibians, among them three species of frog and toad (Bufo melanostictus, Rhacophorus maculates, Rana cyanophlyctia) are available found in the sundarban. Although, 35 species of reptiles have been recorded but 19 ecologically important species (Crocodylus porosus, Gavialis gangeticus, Hemidactylus flaviviridis, Eublepharis fasciolatus, Mabuya dissimilis, Varanus bengalensis, Naja naja, Ahaetulla ahaetulla, Python molurus, Microcephalophis contoris, Ptyas mucosus, Vipera russelli, Dryophis mycterigans, Lycondon aulicus, Pelochelys bironi, Morenia petersi, Cheonia mydas, Trionyx hurun and Kachuga tecta) are common from sundarban.

Twenty species of shrimps, 8 species of lobsters, 7 species of crabs, 42 species of mollusks and 225 species of fish among them 120 species of commercially important fishes are available harvesting by the fisherman. The sundarban mangrove ecosystem provides roosting and breeding sites for number of bird species that feed in adjacent cultivated area. At least 290 species of bird recorded from sundarban. 
The varied and colourful bird-life to be seen along its waterways is one of the Sundarbans' greatest attractions. A total 315 species have been recorded, including about 95 species of waterfowl and 38 species of raptors. Among the many which may be readily seen by the visitor are no less than nine species of kingfisher, including brown-winged and stork-billed kingfishers, Pelargopsis amauropterus (Not threatened) and P. capensis, respectively; the magnificent white-bellied sea-eagle Haliaeetus leucogaster which, at a density of one individual per $53.1 \mathrm{~km}$ of waterways, is quite common; also the much rarer grey-headed fish eagle Ichthyophaga ichthyaetus (Not Threatened), Pallas's fish-eagle Haliaeetus leucoryphus and several other raptors. Herons, egrets, storks, sandpipers, whimbrel, curlew and numerous other waders are to be seen along the muddy banks and on the chars or sandbanks which become exposed during the dry season. There are many species of gulls and terns, especially along the coast and the larger waterways. Apart from those species particularly associated with the sea and wetlands, there is also a considerable variety of forest birds such as woodpeckers, barbets, shrikes, drongos, mynahs, minivets, babblers and many others. Scott gives further details of the avifauna.

Some 53 reptile species and eight of amphibians have been recorded. Of these mugger Crocodylus palustris is now extinct, probably as a result of past over-exploitation, although it still occurs in at least one location nearby. Estuarine crocodile $C$. porosus still survives but its numbers have been greatly depleted through hunting and trapping for skins. There are also three species of monitor, Varanus beingalensis, $V$. flavescens and $V$. salvator, and Indian python Python molurus (Not Threatened). Four species of marine turtle have been recorded from the area, olive ridley Lepidochelys olivacea (Endangered) being the most abundant. Green turtle Chelonia mydas (Endangered) is rare due to excessive fishing, while loggerhead Caretta caretta (Endangered) and hawksbill Eretmochelys imbricata (Critically Endangered) are not common although there have been some reported on the beaches. River terrapin Batagur baska (Endangered) is also present. The eighteen recorded snake species include king cobra Ophiophagus hannah and spectacled cobra Naja naja, three vipers and six sea-snakes.

Over 120 species of fish are reported to be commonly caught by commercial fishermen in the Sundarbans. Only brackish water species and marine forms are found in the Indian Sundarbans, freshwater species being totally absent. This may be assumed to apply also to the Bangladesh Sundarbans, except possibly in the eastern portion where there is freshwater in Baleswar River. Mention should also be made of mud-skippers or gobys which occur in large numbers and are a characteristic feature of mangrove swamps.

Crustacea account for by far the largest proportion of animal biomass, with an estimated 40 million kilograms of fiddler crabs and 100 million kilograms of mud crabs. The nutrient-rich waters of the Sundarbans also yield a considerable harvest of shrimps, prawns and lobsters. The area supports a varied insect population including large numbers of honey-bees, honey and beeswax being among the economically important products. The insect life of the Sundarbans has been little studied.

\section{Vegetation}

The mangroves of the Sundarbans are unique when compared to non-deltaic coastal mangrove forest. Unlike the latter, the Rhizophoraceae are of only minor importance and the dominant species are sundry, Heritiera fomes, from which the Sundarbans takes its name, and gewa, Excoecaria agallocha. The reason for this difference is the large freshwater influence in the north-eastern part and the elevated level of the ground surface. The Sundarbans can be classified as moist tropical serial forest, comprising a mosaic of beach forest and tidal forest. Of the latter, there are four types: low mangrove forests, tree mangrove forests, salt-water Heritiera forests and freshwater Heritiera forests. Sundarbans West occurs within the salt-water zone, which supports sparse Ecoecaria agallocha, a dense understory of Ceriops, and dense patches of hantal palm Phoenix paludosa on drier soils. Dhundal and passur Xylocarpus spp., and Bruguiera occur sporadically throughout the area. Sundri and gewa cover most of the Sundarbans but Oryza coarctata, Nypa fruticans, and Imperata cylindrica 
are prevalent on mud flats. Large stands of keora Sonneratia apetala are found on newly accreted mudbanks and provide important wildlife habitat.

\section{Ecosystem}

The Sundarbans region has a warm humid climate. It receives rainfall during the southwest monsoon season, which starts in June and continues until October, with occasional rainfall throughout the year. Due to gentle slope of the coast and large tidal amplitude, tidal water penetrates at an average distance of $110 \mathrm{~km}$ inland from the shoreline and in some areas, the effect of the tides is felt over $300 \mathrm{~km}$ inland. The geomorphology of this mangrove estuary is funnel-shaped with numerous linear, tidal mud flats and a network of tidal channels. These mud flats lie more or less perpendicular to the shoreline and parallel to the direction of tidal flow. Presence of large tidal flats is a common feature in tide-dominated mangrove estuaries, where strong tidal currents work and rework the sediments to create such tidal flats. In the Sundarbans, during the monsoon rains, the estuarine regime is influenced by the interaction of the headwater discharge and the tides, which together influence the seaward drift of the sediment. During reduced inflow of freshwater, strong tidal currents govern the estuary and influence the upstream sediment movement. The tidal mud flats provide suitable microenvironment for colonization of the mangrove plants, which grow into dense and tall mangrove plant communities.

Now the main deltaic region and highest level of freshwater run-off are restricted to Bangladesh Sundarbans. As a result, the salinity of Bangladesh Sundarbans is much lower than that of the Indian Sundarbans. Because of this, the Bangladesh Sundarbans is characterized by the presence of large population of less saline-tolerant or freshwater-loving species such as Heritiera fomes and Nypa fruticans, whereas in the Indian part of the Sundarbans, low stands of E. agallocha , Agiceras corniculatum and Ceriops decandra are common. Even after shifting of the Ganges and Brahmaputra towards the east, the amount of freshwater reaching the Indian part of the Sundarbans makes its salinity lower than that of the other mangrove wetlands of India. Experimental evidences indicate that at high salinity, mangrove plants spend more energy to maintain water balance and ion concentration rather than for net primary production and growth. Hence, increase in salinity due to reduction in freshwater flow would lead to disappearance of the low salinity tolerant species through gradual decline of the population.

Macro-level environmental factors of mangrove wetlands undergo changes both in time and space, and these changes are reflected in the mangrove forest composition and structure. Understanding the development of mangrove forest communities through time, with reference to changing environmental condition, is a basic requirement to develop and implement mangrove conservation and management plans. It covers an area of about 1mha, of which $60 \%$ is located in Bangladesh and the remaining western portion, comprising $40 \%$, lies in India. The Indian part of the Sundarbans is located in the western part of the Ganges-Brahmaputra delta. Ganges and Brahmaputra rivers are snow-fed and have a number of large distributaries and rivulets through which freshwater is supplied to the Sundarbans mangroves throughout the year. Because of this, salinity of the water both within the mangrove forest as well as near the sea is lower than that of the sea water even during summer months.

Approximately 2.5 million people live in small villages surrounding the Sundarbans. The area provides a livelihood at certain seasons of the year for an estimated 300,000 people, working variously as wood-cutters, fishermen, and gatherers of honey, golpatta leaves (Nipa fruticans) and grass.

Fishermen come in their boats from as far away as Chittagong and establish temporary encampments at various sites along the coast, where they remain until the approach of the monsoon season in April before returning to their homes. Apart from the large numbers of people employed by contractors in the commercial exploitation of sundri and other tree species, the local people are themselves dependent on the forest and waterways for such necessities as firewood, timber for boats, poles for 
house-posts and rafters, golpatta leaf for roofing, grass for matting, reeds for fencing and fish for their own consumption. The season for collecting honey and wax is limited to two and a half months commencing annually on 1 April. Thousands of people, having first obtained their permits from the Forest Department, enter the forest in search of bee nests which are collected and then crushed to extract the honey and wax.

\section{Ecotourism}

Now at present Bangladesh forest department has taken some of steps to develop ecotourism in the sundarban. The following scope of nature sundarban is very much interesting for ecotourism as-the world largest tract mangrove forest, UNESCO declared $798^{\text {th }}$ World Heritage site in 1997, unique tourism spot of Bangladesh, diversive nature and culture, easy access and low cost journey, most attractive recreational journey, rich biodiversity, rich sorts of field for research and education, historical and cultural interest, bird watching field, herbal tour, educational survey tour and excursion, field and cruising, beautiful tranquil scenery, wild life sanctuary and watching, field of big game watching, tropical beaches and sea, beach relaxation and recreation, great field of photo season, largest participatory ecology, boat journey, sightseeing, archaeological interest, excellent arts and craft, field of voyage and religion, sources of income generation and poverty alleviation, excellent climate change neutralizer, source of medicine and source of huge revenue.

\section{Conservation Value}

The mangrove forests of the Sundarbans are among the richest and most extensive in the world. The Bangladesh portion, covering six percent of total land area, represents over half of the country's remaining natural forest. The forests and waterways support a wide range of fauna, including a number of species threatened with extinction. As one of the most biologically productive of all natural ecosystems, it is of great economic importance as a source of timber, fish and numerous other products.

\section{Management Constraints}

A long-term ecological change is taking place in the Sundarbans, due to the eastward migration of the Ganges, abandonment of some distributaries, diversion of water and withdrawals for irrigation (Up to $40 \%$ of the dry season flow of the Ganges has been diverted upstream, following the completion of the Farraka Barrage in India in 1974). Decreased freshwater flushing of the Sundarbans results in increased saline intrusion, particularly in the dry season. Concern has been expressed about recent indications of apparent deterioration in the flora, including localised die-back of sundri, commercially the most valuable of tree species. Top-dying of sundri is most likely associated with the decrease in freshwater flow, either as a direct effect of increasing salinity or other associated edaphic changes. A gradual replacement of Heritiera with Excoecaria, therefore, is a likely long-term effect. While deterioration in the vegetation is already well-documented and is the subject of continuing study, no attention has yet been given to the possible effects which these changes might have on the fauna. It is perhaps significant, however, that the stocking of spotted deer appears lower in western areas, where salinity is highest, than in the east where it is lowest. Oil spills are another potential threat and could cause immense damage, especially to aquatic fauna and seabirds and probably also to the forest itself. There have been several spillages from tanks passing nearby. The most recent incidence due to ship wreckage occurred in August 1994 when a Panamanian cargo ship capsized near Dangmari Forest Station. Oil from the fuel tank spread about $15 \mathrm{~km}$ downstream from the ship and affected a considerable part of the Sundarbans mangrove area. It was found to cause instant mortality of seedlings of Heritiera and Excoecaria while patches of grass which were covered by oil also died. Mortality of fishes, shrimps and other aquatic animals from the Sundarbans has been reported to due the incidence.

Cyclones and tidal waves cause some damage to the forest along the sea-face, and are reported to result occasionally in considerable mortality among spotted deer. The most immediate threat is overexploitation, both of timber resources, which may have already taken place, and also of the fauna. Agricultural encroachment has already occurred to a limited extent on the eastern and western boundaries and, with increasing population pressure in surrounding settled areas, could reach serious proportions unless checked. Fishermen's camps are a major source of disturbance. There is extensive 
illegal hunting and trapping, not only by fishermen and woodcutters but also reportedly by naval and military personnel from Hiron Point in Sundarbans South Wildlife Sanctuary. A total of 118 offenses were recorded and over 3,300m of deer nets removed between 1981/82 and 1986/87, but this poaching is now rare. The capture of adult marine turtles and Batagur in fishing nets and their subsequent killing and marketing for food is a potentially serious problem. Smugglers moving to and from India with contraband goods also use the area.

The Sundarbans has been notorious for its man-eating tigers since the $17^{\text {th }}$ century. Numbers of reported deaths has varied from 0 to 47 (mean $=22.1$ ) per annum during the period 1947-1983. In 1988, 65 deaths were reported during a four-month period. Noting that tigers that hunt man like any other prey occurred only in the south and west, Hendrichs hypothesized on a possible linkage between high salinity levels, due to the absence of freshwater, and man-killing. This is not substantiated by more recent analyses, which suggest that man-killing may be at least partly correlated with the availability of easy prey (humans) and the frequency of man-tiger interactions.

In response to the question about the main cause of the forest degradation and biodiversity reduction the foresters have made comments that the principal causes of forest degradation and biodiversity reduction are illegal felling, the natural calamities (like-tidal surge, cyclone, sidr, aila, saline water intrusion etc.) and water pollution as well. It is noteworthy here that the causes of forest degradation and biodiversity reduction are very much natural and man-made. The forest diversity also threatened by unabated poaching, hunting, illegal felling of trees, diseases, unplanned and over extraction of resources, insufficient conservation effort, deterioration of law and order situation, corrupt practices of the forest officials and unscrupulous traders etc. On the other hand, besides these anthropogenic activities and natural calamities, some ecological changes like increases in salinity, outbreak of diseases like "top dying" of the sundari trees pose a serious threat to rich biodiversity of the Sundarbans. Top dying problem of Sundri (Heritiera fomes), the burning problem of Sundarbans is directly correlated increasing soil water salinity and insufficient upstream freshwater flush. The rather alarming and widespread phenomenon of sundari dieback, though to be due to the changes are accompanying this phenomenon. Other well known tree species that were once harvested regularly, before the imposition of the moratorium on the felling in the natural forest, include; Amur (Amoora cucullata), Baen (Avicennia officinalis), kankra (Bruguiera gymnorrhiza), keora (Sonneratia apetala) and passur (Xylocarpus menkongensis). Diversion of the natural rivers, construction of embankments, dams and bridges in the upstream as well as the decreased flow of freshwater in the rivers resulted in the increases of the salinity level and over silting in many places and caused subsequent changes in the mangrove ecosystem. Many other exotic species have been introduced in the Sundarbans mangrove ecosystems, particularly in areas around the forest offices. It is apprehended that these exotic species many pose a threat to the native variety of mangrove species.

For overpopulation pressure many types of plants, animals and birds species are extinct. In this regard, in response to the question about what types of plans, animals and birds are declining, the foresters have been mentioned that the sundari tree and other kinds of plants and tiger, crocodile, modontak, strark, different species of deer etc. They have pointed out that the main causes of extinction of these plants, animals and bird species are destruction of the residence of wild life reservation. They have suggested that that creating fearless forest will protect them.

Many factors contribute to mangrove forest loss, include the charcoal and timber industries, legal and illegal logging, oil spill, tourism industries, unplanned development projects, urban growth pressures, and mounting pollution problems. However, one of the most recent and significant causes of mangrove forest loss in the past decade has been the consumer demand for luxury shrimp, or "prawn", and the corresponding expansion of destructive production methods of export oriented industrial shrimp aquaculture along the forest. The Khulna newspaper mills alone is estimated to use and discharge 30,000 of processed water laden with chloride and dissolved and suspended solids everyday along with the municipal wastes of the regional cities.

The marsh crocodiles, once abundant, are already extirpated. The salt-water crocodile (Crocodylus porosus) still survives in low densities and like the marsh crocodilies its population is being reduced through indiscriminate hunting and trapping for skins, quite apart from the immediate conflict with men. Despite an apparent reduction in illegal trade in its skin, the population shows little sign of 
recovery. Some 30 species of snakes have been recorded in the sundarban reserve forest and there appears to have been a general decline in densities or at least in their sighting particularly in the past two decades. The rock python (Python molurus) is one of the valuable reserve forest snake species, which is said to have declined over recent years. A number of species like javan rhinoceros (Rhinoceros sondaicus), water buffalo (Bubalus bubalis), swamp deer (Cervus duvauceceli), gaur (Bos gaurus), hog deer (Axix porcinus) and marsh crocodile (Crocodilus palustris) became extinct during the last 100 years from the Sundarbans.

Many environmentalist opined that far reaching changes are taking place in the delicate ecosystem due to growing pollution and human interference in the areas adjacent to the forest. The mongla port on the northern edge of the forest and its associated marine traffic are a frequent source of oil spill and there is a permanent risk of accidents from handling chemicals in the port area. Many factors contribute to mangrove forest losses as: charcoal and timber industries, legal and illegal logging, oil spill, tourism industries, unplanned development projects, urban growth pressures and shrimp culture. The biodiversity of sundarbans has been under threat for various reasons. There has been increasing conversion of the forestland for faulty practice of agriculture, many paddy and shrimp farming and human settlement. The following reasons have been identified as major threats to the biodiversity resources of the Sundarbans as: population pressure, expansion of agricultural land, construction of houses, roads, embankments, bridges etc.; indiscriminate shrimp fry collection and conversion of forest lands into shrimp farming; unscrupulous harvesting of forest and fisheries resources and insufficient measuring to regenerate the resources; irrational use of chemical fertilizers and insecticides in croplands and adoption of unplanned agricultural practices resulting in low productivity of the forest and fisheries; introduce to exotic plants in the sundarbans areas cause threats to the native mangrove species; lacks of appropriate policies for proper management and training of forest officials or other concerned people working in the sundarbans areas and lack of proper rules and laws for natural resources harvesting etc. In response to the question about overcome the problems about the main causes of the forest degradation and biodiversity reduction, they have told that these problems can be overcome naturally. They have also told that it is necessary to make general people conscious about the law of increase the number of employee, necessary to make boundary of the forest, make profession of the local people of the forest zone and finally make conscious of the people about the importance of forest grown properly.

In 1988, a disastrous cyclone at Debaucher caused much harm for the adjacent people and distracted the forest and the fisherman's village. The researcher has categorizer the interviewees into eleven categories. If it analyses the answers of them it has been found that the actual condition of the sundarban is not so well.

In answer to the question about the natural destruction and its impact of biodiversity of sundarban the two divisional forest officers have made comments that this has many negative effect and influence the biodiversity of the forest. In reply to the question about the strength and weakness of the management system four range officers have point out that there are many circle to improve the sundarbans and they have mentioned that the weakness is only the rules and regulations are not maintained. So, to improve the strength of the forest rules and regulations should be mentioned strongly. In answer to another question about the role of the forest in economy four range officers have mentioned that the forest can play a vital and pivotal role to improve the whole economic system of our country in general and the people of the sundsrbans region in particular.

No discussion of the ecology of the Sundarban Reserve Forest (SRF) would be complete without noting the problem of water pollution. Pollution from various sources is a major determinant of water quality both in the river and costal area of sundarbans. An approximate one third of the nearly 600,000 hectors of the sundarbans area consists of the tidal channels, and most of the reminder is subject to periodic inundation, impact of water pollution are potentially very wide widespread. Pollutants are carried into the sundarbans and ultimately in to the Bay of Bengal from various upstream sources including the industrial unit, municipal wastes, agrochemicals and port sewages in the mongla and Khulna region. 
The main threat today may come from outside the area in the form of pollution. Mongla is a second largest sea port on the northern edge of the sundarbans. The port and its associated marine traffic is a frequent source of oil spills and there is a permanent risk of accident by chemicals.

Oil spills during transfer of refined petroleum from tankers to receiving stations in mongla and Khulna, fuel oil spillage and discharge of oily ballast and sewages from some 600 ships anchored in mongla port and residual heavy oil sludge, lubricants and engine oils discharged during ship breaking operations in Khulna are major sources of the water pollution affecting the sundarbans.

Due to natural processes the role of the sundarbans to discharge the water of the ganges and Brahmaputra catchments is decreasing as waterways are shifting eastwards. As a result, the salinity of the sundarbans is increasing particularly in the western region. Further, the total annual discharge is decreasing due to intensifying land use (dam, irrigation) upstream. The role of this of these changes is not yet clear, but is evident that it will influence wildlife populations and vegetation in the long term. In reply to the question about the types of the plantation to restore the forest coverage in degraded areas the foresters have mentioned that plantation of new trees like rain tree, Korai, Babla, Chambul, Akasmoni, Shirish, Mehgoni etc., are needed for the forest coverage in degraded area.

\section{CONCLUSION}

The ecology of the mangrove wetlands is influenced by a number of macro-level physical forces. Among them, the quantity and periodicity of freshwater flow plays a significant role in determining the species diversity, biomass and forest structure. This is especially important for river-dominated mangrove wetlands since the flora of these mangrove wetlands is more susceptible to reduction in freshwater flow than tide-dominated mangrove wetlands. Secondly, species selection for plantation or restoration of degraded mangroves needs to be based on the currently available species. Any attempt to reintroduce the low-saline species that were lost from a mangrove wetland might not succeed without increasing the freshwater flow. For example, attempts to reintroduce Son- neratia apetala, Xylocarpus granatum and Bruguiera gymnorhiza in the Pichavaram and Muthupet mangrove wetlands failed because of high soil salinity. Thirdly, river-dominated mangroves characterized by high nutrient influx and strong out-welling from mangrove forests, play a significant role in maintaining the fishery production of the adjacent coastal waters. Hence, reduction in freshwater flow would affect the amount of nutrient exported to coastal environment and thereby affect fishery production. Thus, in order to save the current floral diversity and biomass of the mangrove wetlands as well as fishery production of the adjacent coastal waters, prevention of further reduction in freshwater inflow into the mangrove wetlands should be one of the main objectives of mangrove conservation and management plans.

\section{REFERENCES}

Alongi DM. Boto KG. and Robertson AI. 1992. In Tropical Mangrove Ecosystem (eds Alongi DM. and Robertson AI.), American Geophysical Union, Washington DC, pp. 251- 292.

ASB (Asiatic Society of Bangladesh), 2004. The Sundarbans. In: Banglapedia: National Encyclopedia of Bangladesh. Asiatic Society of Bangladesh, Dhaka. (Multimedia CD, English Version).

Baidya A. and Choudhury A. 1986. In The Mangroves (ed. Bhosale L J.), Shivaji University, Kholapur.

Blasco F. 1984. In The Mangroves of India, French Institute of Pondi- cherry, Pondicherry, 1975. 3. Blasco, F., in Mangrove Ecosystem: Research Methods (eds Snedaker SC. and Snedaker JG.), UNESCO, Paris, , pp. 18-35.

Blasco F. and Aizpuru M. 2002. Depletion of the mangrove of continental Asia, Wetlands Ecol. Manag. 9: 245-256.

Blower J. 1985. Sundarbans Forest Inventory Project, Bangladesh. Wildlife conservation in the Sundarbans. Project Report 151. Overseas Development Administration, Land Resources Development Centre, Surbiton, UK. 39 pp. 
Bunt JS. Williams WT. and Duke NC. 1982. Aust. J. Bot ., 30 , 401-404. 36. Clough, B. F., (in Tropical Mangrove Ecosystem (eds Alongi, D. M. and Robertson, A. I.), American Geophysical Union, Washington DC, 1992), pp. 225-250.

Chaffey DR. and Sadom JH. 1985. Sundarbans Forestry Inventory Project. A glossary of vernacular plant names and a field key to trees. Overseas Development Administration, Land Resources Development Centre, Surbiton, UK. 23 pp.

Choudhuri AB. and Choudhury A. 1994. In Mangroves of the Sun- derbans: Volume 1 India, IUCN, Bangkok, 1994.

Christensen B. 1984. Ecological aspects of the Sundarbans. FO: TCP/BGD/2309 (Mf). FAO, Rome. $42 \mathrm{pp}$.

Duke NC. 1992. Tropical Mangrove Ecosystem (eds Alongi DM. and Robertson AI.), American Geophysical Union, Washington DC, pp. 63-100.

Habib MG. 1989. Wildlife management of the Sundarban - a case study. In: Karim, GMME, Akonda, AW. and Sewitz, P. (Eds), Conservation of wildlife in Bangladesh. German Cultural Institute/Forest Department/Dhaka University/Wildlife Society of Bangladesh/Unesco, Dhaka. pp. 161-168.

Hendrichs H. 1975. The status of the tiger Panthera tigris (Linne, 1758) in the Sundarbans mangrove forest (Bay of Bengal). Saugetierkundliche Mitteilungen 23: 161-199.

Husain KZ. Sarker SU. and Rahman MM. 1983. Summer birds of the Sundarbans' 'Nilkamal Sanctuary', Bangladesh. Bangladesh Journal of Zoology 11(1): 48-51.

Hussain KZ. and Acharya G. 1994. Mangroves of the Sundarbans. Volume two: Bangladesh. IUCN, Bangkok, Thailand. ISBN: 2831702100.

Islam I.AKM.N. 1973. The algal flora of the Sundarbans mangrove forests, Bangladesh. Bangladesh Journal of Botany 2(2): 11-36.

Kathiresan K. and Bingham BL. 2001. Biology of mangroves and mangrove ecosystem. Advances in Marine Biology, 40: 81-251.

Khan MAR. 1986. Wildlife in Bangladesh mangrove ecosystem. Journal of the Bombay Natural History Society, 83: 32-48.

Mukherjee AK. 1975. The Sundarbans of India and its biota. Journal of the Bombay Natural History Society, 72: 1-20.

Olivier RCD. 1979. Wildlife and management in Bangladesh. UNDP/FAO Project No. BGD/72/005. Forest Research Institute, Chittagong. $121 \mathrm{pp}$.

Salter RE. 1984. Integrated development of the Sundarbans, Bangladesh: status and utilization of wildlife. FO: TCP/BGD/2309(MF). Report No. W/R0034. FAO, Rome. 59 pp.

Seidensticker J. and Hai MA. 1983. The Sundarbans Wildlife Management Plan: conservation in the Bangladesh coastal zone. IUCN, Gland, Switzerland. 120 pp.

Siddiqi NA. 1999. Status and conservation of mangroves in the Indian sub-continental, paper presented in the symposium on mangrove, ISME, Bali.

Siddiqi NA. 2001. Mangrove forest in Bangladesh (Institute of Forestry and Environmental Science, University of Chittagong), pp201.

Siddiqui HSA. 2009. Sunderban Vromon O Sunderban Vromon Prosango (Sunderbans and visit to the Sunderbans). Published by Angikar Prokashoni, 38 Banglabazar, Dhaka 288pp.

Smith ITJ. 1992. In Tropical Mangrove Ecosystem (eds Alongi DM. and Robertson AI.), American Geophysical Union, Washington DC, 1 pp. 101-136.

Swaminathan MS. 1994. In Conservation of Mangrove Genetic Resources, M.S. Swaminathan Research Foundation, Chennai, pp. 87-95.

Thom BG. 1984. In Mangrove Ecosystem: Research Methods (eds Snedaker SC. and Snedaker JG.), UNESCO, Paris, pp. 3-17.

Woodruff C. 1992. Tropical Mangrove Ecosystem (eds Alongi DM. and Robertson AI.), American Geophysical Union, Washington DC, pp. 7-42. 